\title{
INTINSIFICATION OF RED TILAPIA CULTURE IN LAKE MARIUT, EGYPT
}

\author{
M. A. Essa', E. H. EL-Ebiary ' and A. A. Nour ${ }^{2}$
}

1- National Institute of Oceanography and Fisheries, Alexanderia, 2- Department of Animal Production, Faculty of Agriculture (Damanhour), Alexandria University

\section{SUMMARY}

The present study was conducted to investigate the optimum management conditions required for the culture of red tilapia reared in net-enclosures (hapas) fixed in 14 feddan (5.9 ha) marginal area at Southwest Basin of Lake Mariut, Egypt. The results indicated that :

The least cost of dietary protein from soybean meal could be used in replacement of the expensive protein sources (fish or meat meal) for formulation of practical diets with no apparent loss in fish growth and feed utilization parameters ; 2) the more frequent feeding with correspondingly smaller amounts must therefore be given over other methods for red tilapia culture; 3) feed quantity and feeding frequency are a strong determinant for fish growth and production, and 4) using demand feeder gives the fish chance to obtain at all times the food it requires, ensure the optimum management conditions for red tilapia growth and production. After 10 weeks rearing period, fish advanced fry gained $10.53-17.58 \mathrm{~g}$. (fingerlings) and yielded about $1.67-3.29 \mathrm{~kg} / \mathrm{m}^{3}$

Keywords: Red tilapia, intensive culture, lake Mariut, management conditions.

\section{INTRODUCTION}

Although there is considerable potential for fish culture in Egypt, the present contribution to domestic fish production from this sector is rather low, $16.7 \%$ from the total Egyptian fish production in 1997 (Magouz, 2000). With a view to increasing fisil production through fish culture management, more attention must be focused on natural lakes using its numerous marginat areas to find a new semiintersive or intensive pen culture method (net-enclosures or hapas ) .Pen culture is playing an increasingly important role in the world production of fish culture not only because of the market value marine species but also the more ubiquitous tilapia (Essa 1999) for the Egyptians.

Scientific investigations concerning the possibility of culturing natural water resources, lagoons and lakes, were made by many workers (Essa and Salama 1989 ; Essa et al.,1989 ; Mckinley, 1994 and Loverich , 1996). This type of fish culture is practically well - developed in China. The current trend is to convert the shallower zones of natural lakes into large pen fish farms and ponds, for more intensive fish culture (FAO, 1983)

Red tilapia, Oreochromis sp., is tolerant of a wide range of environmental conditions (Dowidar and Essa , 1988). Therefore, the present study aims to investigate the optimum conditions for red tilapia culture in net-enclosures fixed in marginal area at Lake Mariut, Alexandria , Egypt.

\section{MATERIALS AND METHODS}

The present study was carried out for ten weeks in 14 feddan ( 5.9 ha) marginal area at Southwest Basin of Lake Mariut, in the East of El-Mex Research Station, National Institute of Oceanography and Fisheries, Alexandria.

Taiwan's red tilapia, which was produced by interbreeding between Oreochromis niloticus male and mutant of Oreochromis mossambicus female (Liao and Chang, 1983) were introduced from Maruit Fish Farming Project, Alexandria .150 fish fingerlings per $\mathrm{m}^{3}$ net -enclosure with a mean body weight of $0.61-0.64 \mathrm{~g}$ were stocked in net-enclosures, each 1000 liter, at different management conditions to estimate the suitable management conditions which produce the maximum performance in red tilapia culture in net-enctosures. Net-enclosure consisted of wooden rods fences between the poles of which a fine mesh nylon nets were arranged . In order to prevent fish from escaping, the top of the net was 30 $\mathrm{cm}$ above the water level and small lead pieces were fixed on the lower parts of the nets, which were buried in the bottom of the lake.

Four experiments were conductad seperately in order to investigate the optimum management conditions dietary protein source, feeding level, frequency of feeding and feeding method for intensive red tilapia culture. 
The following experiments were conducted: Experiment (1) : Optimum dictary protein source

Four diets were formulate to contain the following dietary protein sources:

Diet 1 : fish and soybean meals.

Diet 2 : fish meal.

Diet $3:$ meat meal ; and

Diet 4 : soybean meal.

Fingerlings with a mean body weight of $0.61-0.64 \mathrm{~g}$ were stocked in net enclosures with density rate 150 fish $/ \mathrm{m}^{3}$. Fish were fed on $5 \%$ of its live body weight / day from the corresponding diet and
adjusted accordingly at bi-weekly intervals.

Table 1. Feed ingredients and chemical analysis of the experimental diets containing different dietary protein sources for red tilapia

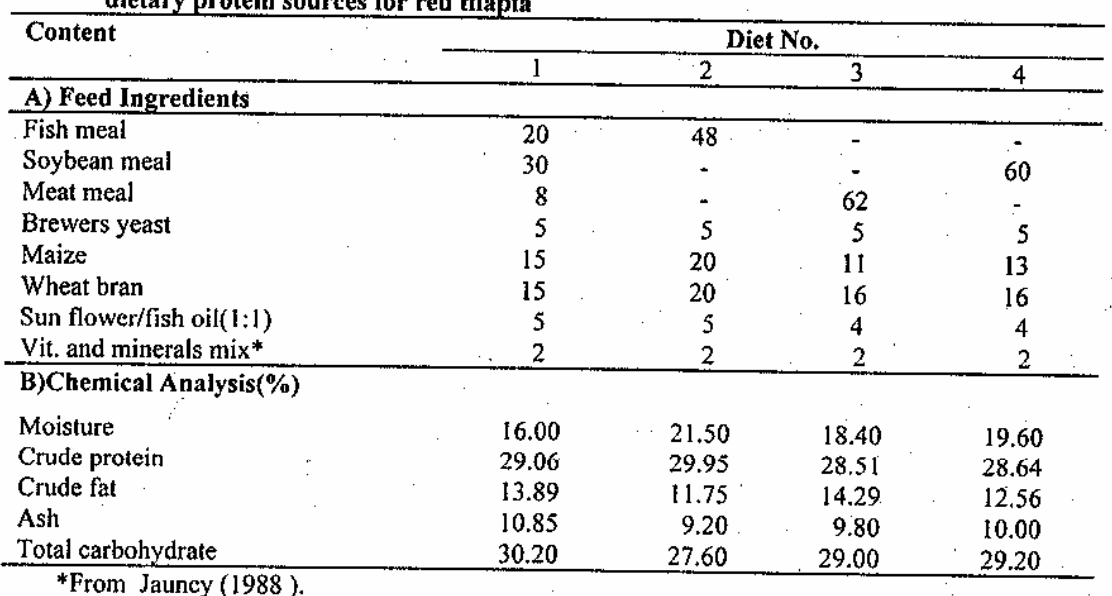

Experiment (2): Optimum feeding levei

Three levels of feeding $(5 \%, 7.5 \%$ and $10 \%$ of body weight $/$ day) were tested with fish fed on diet 1 which containing $29 \%$ crude protein. Fingerlings were stocked at 150 fish $/ \mathrm{m}^{3}$ for 10 weeks rearing period.

Experiment (3): Feeding frequency

Two and three feed frequencies were applied daily, 10 weeks through rearing period were tested at fish fed on the control diet (diet 1) containing $29 \%$ crude protein and $5 \%$ feeding rate of its live body weight/ day. Fingerlings were stocked, at a density of $150 \mathrm{fish} / \mathrm{m}^{3}$.

Experiment (4): Feeding method

Three feeding miethods ( clock operated automatic belt feeder,demand feeder and manual feeding) were used to feed the fish stocked at a rate of $150 \mathrm{fish} / \mathrm{m}^{3}$ net-enclosure. Fish were fed on the control diet (diet 1) which containing $29 \%$ crude protein for 10 weeks.

Fish samples

Random fish samples from each net-enclosure were caught at the end of each experiment to determine growth performance, survival rate and feed utilization.

Water quality criteria

water temperature, salinity, $\mathrm{pH}$, dissolved oxygen, and total alkalinity, were measured once a week at $8.00 \mathrm{am}$ in the net-enclusure area throughout the present study according to the American Public Health Association (1985) methods. A Beckman $\mathrm{pH}$ meter was used to determine the $\mathrm{pH}$ values.

Temperature of surface water was recorded also in the shade regularly. Ammonia, nitrate, nitrite and total phosphate were determined according to the methods described by Golterman et al. (1978). Estimation of phytoplankton standing crop was carried out using sedimentation technique. One litre of water samples was collected and concentrated to $100 \mathrm{cc}$. Sub-samples were counted using a research microscope. Results were expressed as the number of units/litre. Zooplankton samples were collected 
by filtering 40 liters of the water inside net-enclusure through $55 \mu$ plankton net \# 25 ; then concentrated samples were counted and the results were expressed as organisms $/ \mathrm{m}^{3}$.

Chemical composition

Chemical analysis of the tested diets were carried according to the methods of the AOAC(1990). The average feed conversion for each fish was calculated as the ratio of the average amount of feed given /fish to the average of weight gained/fish. Average weight gain, specific growth rate (SGR\%/day), survival rate and total yield $\left(\mathrm{kg}\right.$ fish $\left./ \mathrm{m}^{3}\right)$ for each of the treatments were estimated. Feed cost $/ \mathrm{kg}$ fresh fissile were estimated according to this equation, Feed Cost $/ \mathrm{kg}$ fresh fissile $=\mathrm{FCR} \times$ Cost $/ \mathrm{kg}$ diet.

Statistical analysis

Analysis of variance, F-test and Duncan's multiple range test were employed in evaluating the experimental results according to Snedecor and Cochran (1974).

\section{RESULTS AND DISCUSSION}

Fish rearing in net-enclosures (hapas) is a relatively recent activity in Egypt. During the production cycle several interacting factors have to be optimized to give maximum production efficiency such as: water quality, supplemental feeding, feeding level, frequency and method of feeding (Mckinley, 1994 and Tacon, 1997).

\section{1- Water quality criterias}

Results in Table 2 show the values of water quality criterias in the experimental net-enclosure. Water temperature averaged $23.76 \pm 1.08 \mathrm{C}^{\circ}$. This value is beneficial for fish survival and growth (Huet, 1972; Dowidar and Essa, 1988). Water salinity was $5.26 \pm 0.16$ ppt. This level classifies such water as brackish. Watanabe et al. (1991) showed that red tilapia could survival well in a wide range of salinity.

Table 2. Average values of water quality criterias in the net-enclosures area at Southwest Basin of Lake Maruit

\begin{tabular}{|c|c|}
\hline Parameters & Averinge \\
\hline Water temperature ${ }^{\circ} \mathrm{C}$ & $23.76 \pm 1.08$ \\
\hline Salinity $(\mathrm{g} / 1)$ & $5.26 \pm 0.16$ \\
\hline pH & $7.90 \pm 0.11$ \\
\hline Dissolved oxygen ( $\mathrm{mg} / \mathrm{l}$ ) & $5.40 \pm 0.14$ \\
\hline Total alkalinity (mg/l) & $186.67 \pm 28.10$ \\
\hline Total phosphate $(\mathrm{mg} / 1)$ & $0.04 \pm 00.00$ \\
\hline $\mathrm{No} 3+\mathrm{No} 2(\mathrm{mg} / \mathrm{l})$ & $0.06 \pm 00.00$ \\
\hline $\mathrm{NH3}-\mathrm{N}(\mathrm{mg} / 1)$ & $0.12 \pm 00.00$ \\
\hline Biochemical oxygen demand(BODmg/l) & $4.70 \pm 0.67$ \\
\hline Chemical oxygen demand (CODmg/1) & $5.06 \pm 0.86$ \\
\hline Phytoplankton ( unit / I) & $2,270,761$ \\
\hline Zooplankton ( individ. $/ \mathrm{m}^{3}$ ) & 93,244 \\
\hline Benthos (org. $/ \mathrm{m}^{2}$ ) & 6,650 \\
\hline
\end{tabular}

Water $\mathrm{pH}$ value of net-enclosures area was laid in the alkaline side $(7.90 \pm 0.11)$. Hepher and Pruginin (1988) reported that water $\mathrm{pH}$ from 6.5 to 9.0 is quite reasonable for fish farming. The quality of water depends also on its content of dissolved oxygen. In the present study, dissolved oxygen was nearly over $5.0 \mathrm{mg} /$ I. Swingle (1969) considered that dissolved oxygen concentrations below $3.5 \mathrm{mg}$ / 1 were undesirable in tilapia fish culture.

The total alkatinity of the enclosures area averaged $186.67 \pm 28.10 \mathrm{mg} / 1$. According to Maar $e t$ al. (1974), water with total alkalinity over $50 \mathrm{mg} / /$ contain suitable quantity of carbon dioxide to permit plankton production for fish culture.

The results of phyto-and zooplankton production in Table (2) indicate that the area are rich both in density and number of species.

Concentrations of total phosphorus $\left(\mathrm{PO}_{4}\right), \mathrm{NO}_{3}, \mathrm{NO}_{2}$, and $\mathrm{NH}_{3}$ in the experimental area in general are moderate and indicate that, there were no rutrient limitations in the enclosures area. Organic and micro-pollutants measurements, biochemical oxygen demand (BOD) and chemical oxygen demand (COD) indicate that, the BOD was found to be very low where the momentary rate of consumption of 
dissolved oxygen by the microscopic organisms in the water was low. On the other hand, COD, the total amount of oxygen which is required to completely oxidize all of organic matter in water, was higher than that of BOD (Table 2). This is due to the relatively high concentrations of organic matter in the net-enclosures area. In summary, the net-enclosures area is considered to be the most suitable environment for fish culture.

\section{2- Dietary protein source (Exp. 1)}

Results in Table 3 show the performance of red tilapia fed on different dietary protein sources. The results indicated that, diet (4) in which soybean is the major source of protein, give the best improvement in weight gain $(10.53 \mathrm{~g})$, survival percentage $(100 \%)$ and total yield $\left(1.67 \mathrm{~kg} \mathrm{fish} / \mathrm{m}^{3}\right)$ This finding is in agreement with the results obtained by Essa (1993) for Nile tilapia (Oreochromis niloticus). The differences in growth observed between the fish groups fed diet 2,3 and 4 were significance. The different response observed could be due to the nitrogen free extract of soybean meal contains about $10 \%$ sugars, mostly raffinose and stachyose, almost no starch and the rest is composed of hemicellulose and lignin (Smith and Circle, 1978), in addition the soybean have 44\% protein (Hassanen,1997). Apparently the red tilapia is able to digest more from these compounds. Thereby, red tilapia fingerlings possessed a good value of feed conversion ratio, whereas, the fish used 1.33 unit of feed to produce one unit of gain in body weight (Table 3 ). The positive effects of increased soybean meal inclusion in the control diet (1) on fish growth and feed utilization resulted in a lower production cost of fish fed diet (4), compared with those fed diet (2), in which fish meal is the major source of protein, and diet (3), in which meat meal is the major source of protein.

Table 3. Performance of red tilapia culture in net-enclosures and fed diets with different dietary protein sources for 10 weeks

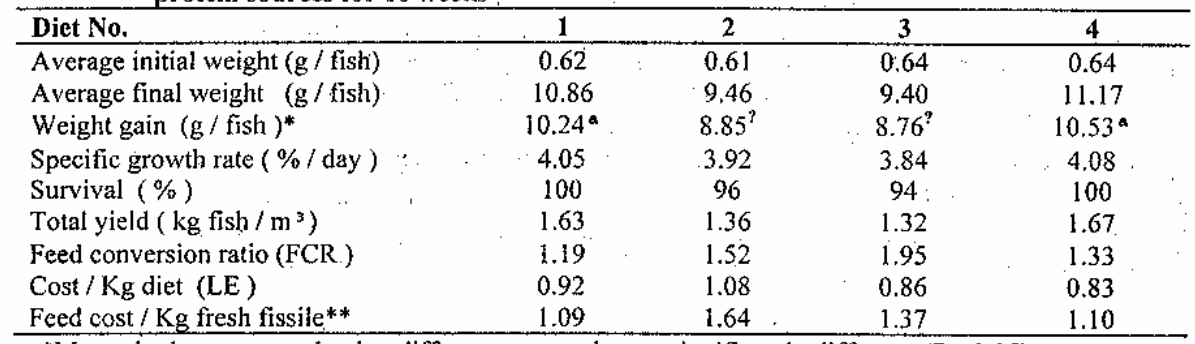

*Means in the same raw having different superscript are significantly different $(\mathrm{P}<0.05)$.

$* *$ Feed cost $/ \mathrm{kg}$ fresh fissile $=$ FCR $X$ Cost $/ \mathrm{kg}$ diet.

Although fish meal is highly palatable for farmed fish and an excellent source of high quality protein and has an essential amino acid profile which approximates almost exactly to the requirements of farmed fish, the results in the present study showed a retrogressive effect of fish meal in diet 2 in comparison with soybean meal in diet 4 , which may be attributed to bad mantifacture of the local (Egyptian) fish meal and the worth storing conditions, which not only prevent the beneficial effect, but also may be harmful for the fish.

In another hand, meat meal is usually limited by specific nutritional imbalances such as ash /mineral imbalances. Therefor the dietary utilization of most vertebrate by-product meals requires careful formulation to obtain the desired overall nutrient profile within the finished aquafeed (Tacon 1993). Omar (1986) said that meat meal is frequently used as an animat protein source in compound fish feed manufacture, although its feed value is generally considered inferior to that of fish meal. Studies of Viola et al.(1988) with hybrid tilapia (Oreochromis niloficts $\times$ O. anreus) and Webster et al. (1992) with channel catish (Ictalurus punctatus) which have shown that cost-effective practical agualeeds can be produced without the use of fish meal with no resulting or apparent loss in fish growth. This will be particularly true for extensive and semi-intensive pond farming systems where fișl, and in particutar those filter-feeding fish species which feed low in the aquatic food chain(such as the Chinese carps and Tilapia spp.), can obtain a large part of their dietary nutrient needs from the consumption of naturally available food organisms.

3- Fecding. level ( Exp. 2)

This experiment was carried out to observe the effect of daily rationing levels on the growth performance, survival, feed conversion ratio and production cost of red tilapia finger!ings. The results 
demonstrated the dependence of growth on the amount of feed given daily, whereas higher feeding intensity resulted in correspondingly greater weight gain, (Table 4). Evidently not all the feed offered was consumed, causing deterio-ration of water quality. Therefore, the $10 \%$ of live weight daily ration gave a statistically confirmed poorer ratio of feed conversion in red tilapia $(2.84: 1)$ than a $5 \%$ and $7.5 \%$ rations. Table (4) indicate that the amounts of feed dispensed were too large and more costly. This finding is in agreement with the results obtained by Meske (1985) for carp, Cyprinus carpio. The author noticed that the higher feeding intensity only achieved modest success in growth rate, but their feed conversion efficiency deteriorated from 2,16 to 2.41 . Similar trends were also observed in grey mullet Nour et al.(1993) and Nile tilapia, O. niloticus. El-Ebiary (1994).El-Dahhar (1993) in Oreochromis niloticus fry $(0.66 \mathrm{~g})$ fed at varying feeding regimes $(3-15 \%$ of $\mathrm{BW})$ found that , increasing feeding rate increased weight gain. The highest overall growth rate was obtained with fry feed at $12 \%$ of BW daily. On the other hand at higher feeding rates the values of PPV\%,PER and ER\% declined. Also Zonneveld and Fodholi (1991) found that feed utilization of red tilapia decreased when the amount of feed increased. The above results are in agreement of my present study. No mortalities were observed in the three groups which recived $5 \%, 7.5 \%$ and $10 \%$ feeding rate.

Table 4. Performance of red tilapia culture in net-enclosures and fed a control diet at different daily feeding levels for 10 weeks

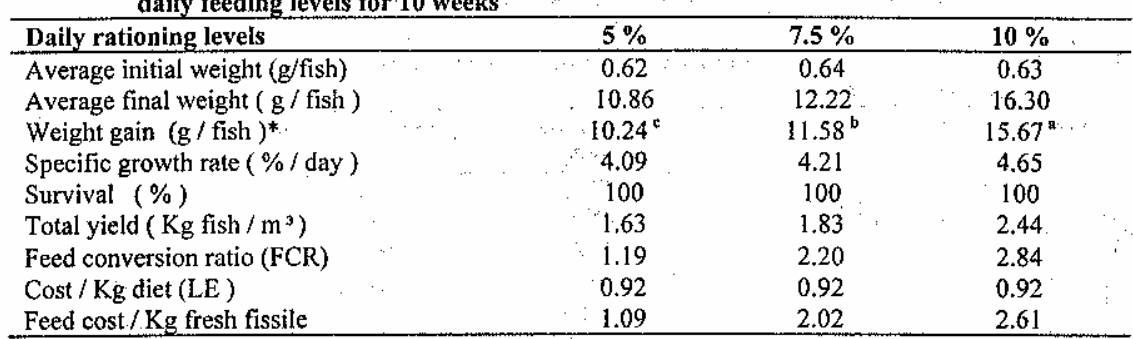

* Means having the different superscript letters are significantly different $(P<0.05)$

4- Feeding frequency (Exp. 3).

The results showed that, the higher feeding frequency (three times daily) was beneficial to growth rate, survival, yield, feed conversion ratio and fish production cost than two times daily (Table 5). These results agree with Hepher (1988) who reported that, multiple feeding results in a more efficient utilization of the feed than a single feeding. El-Ebiary and Zaki (1997) found that, increasing the frequency of feeding from two to four times daily generally improved the growth performance and feed utilization of common carp. Alșo, Essa (2000) obtained the same results in tilapia hybrid (O. niloticus $\mathrm{X} O$. aureus) reared in cages. Kono and Nose (1.971) showed that feeding frequency is apparently related to other parameters such as stomach size, since species with smaller stomachs require more frequent feeding for maximum growth. Omar (1984) she found that increasing feeding frequency from 4 to 6 times daily significantly increased body weight and improved feed utilization of common carp reared in intensive culture. Kayano et al. (1993) reported the young fish fed several times a day could effectively assimilate dietary protein and phospholipids in the muscle. In previous studies, it was found that, between two and four satiated feeding daily were the optimum frequencies for fish (Holm $e t a l$. 1990). Beveridge (1996) recorded that tilapia can not consume their daily requirement of feed for maximum growth in a single meal of short duration. Fish less than 25 grams should be fed at least three times daily.

\section{5- Feeding method ( Exp. 4).}

The present experiment was conducted to see whether red tilapia could be fed exclusively overiong periods on the automatic or demand feeders as well as manual feeding the result in Table 6 indicated that, the best performance came from fish fed on the demand feeders system. This may be because the demand feeder only releases feed when the bait in actually pulled. Also, a demand feeder gives the fish a chance to obtain at all times the food it requires. Statistical analysis of variance indicated that, differences due to the feeding methods are significant in body weight gain (Table 6). The lowest values of growth and survival percentage are obtained by fish fed manually $(0.53 \% /$ day and $58 \%)$ respectively. While the corresponding result for fish fed by demand feeder system are $(0.96 \% /$ day and $70 \%$ ) respectively. The differences in feed conversion ratio between the feeding method resulted in a higher feed cost per $\mathrm{Kg}$ fresh fissile for fish fed manually than those fed by automatic or demand feeder 
systems (Table 6). McGinty and Rakocy (1989) reported that demand feeders can be used to eliminate the work (feed weighing, fish sampling, calculations) and uncertainty of feeding themselves, he recorded also that, with high quality feeds, good growing conditions and effective feeding practices, feed conversion ratios as low as 1.3 have been obtained. .

Table 5. Performance of red tilapia culture in net-enclosures and fed at different feeding frequencies for 10 weeks

\begin{tabular}{|c|c|c|}
\hline Feeding frequency & Two times daily & Three times daily \\
\hline Average initial weight ( $\mathrm{g} / \mathrm{fish})$ & 0.62 & 0.64 \\
\hline Average final weight $(\mathrm{g} / \mathrm{fish})$ & 10.86 & 14,12 \\
\hline Weight gain ( $\mathrm{g} /$ fish $)^{*}$ & $10.24^{\prime}$ & $13.48^{\prime \prime}$ \\
\hline Specific growth rate ( $\% /$ day ) & 4.09 & 4.44 \\
\hline Survival $(\%)$ & 100.00 & 100.00 \\
\hline Total yield ( $\mathrm{Kg}$ fish $/ \mathrm{m}^{3}$ ) & 1.63 & 2.12 \\
\hline Feed conversion ratio (FCR) & 1.19 & 1.15 \\
\hline Cost / Kg diet (LE) & 0.92 & 0.92 \\
\hline Feed cost / Kg fresh fissile & 1.09 & 1.06 \\
\hline
\end{tabular}

${ }^{*}$ Means having the different superscript letters are significantly different $(\mathrm{P}<0.05)$. Table 6. Performance of red tilapia culture in net-enclosures and fed by different feeding
methods for 10 weeks

\begin{tabular}{lccc}
\hline Feeding methods & $\begin{array}{c}\text { Automatic } \\
\text { Feeder }\end{array}$ & Demand Feeder & Manual Feeding \\
\hline Average initial weight $(\mathrm{g} /$ fish $)$ & 39.65 & 40.81 & 39.22 \\
Average final weight $(\mathrm{g} / \mathrm{fish})$ & 74.95 & 79.91 & 56.80 \\
Weight gain $(\mathrm{g} / \mathrm{fish})^{*}$ & $35.30^{\mathrm{B}}$ & $39.10^{\mathrm{a}}$ & $17.58^{\mathrm{c}}$ \\
Specific growth rate $(\% /$ day $)$ & 0.91 & 0.96 & 0.53 \\
Survival $(\%)$ & 68.00 & 70.00 & 58.00 \\
Total yield $\left(\mathrm{Kg}\right.$ fish $\left./ \mathrm{m}^{3}\right)$ & 5.10 & 5.59 & 3.29 \\
Feed conversion ratio $(\mathrm{FCR})$ & 1.15 & 1.12 & 1.26 \\
Cost / Kg diet $(\mathrm{LE})$ & 0.92 & 0.92 & 0.92 \\
Feed cost $/ \mathrm{Kg}$ fresh fissile & 1.06 & 1.03 & 1.16 \\
\hline *Means having the different superscipt letters are
\end{tabular}

*Means having the different superscript letters are significantly different $(P<0.05)$.

Summing up the results of present study, it could be concluded the following :-

1. the least cost of dietary protein from soybean meal could be used in replacement of the expensive protein sources (fish or meat meal) for formulations of practical diets for red tilapia culture ;

2. in practice,attention must be paid to the relationship between the amount of pellets fed daily, the water flow rate and the oxygen content of the water :

3. the more frequent feeding with correspondingly smaller amounts must therefore be given preference over other methods for red tilapia culture in net-enclosures,

4. feed quantity and feeding frequency are a strong determinant for fish growth and production.

5. using demand feeder with $10 \%$ feeding rate for red tilapia lingerlings at three time frequently / day ensure the optimum management conditions for growth rate and feed utilization.

\section{REFERENCES}

A.P.II.A., 1985. American Public tlealih Association. Standard Methods For Examination of Water and Wasterwater., 16 th edition, New York.

A.O.A.C., 1990. Orficial of Analysis of the Association of Onlicial of Analytical Chemists $15^{\text {11s }}$ ed ., Published by the Association of Official Analysis Chemistry . North Nineteenth St . Auite 210 Arlingth , Virginia , 1298pp.

Beveridge, M.C.M., 1996. Cage and pen fish farming . Carrying capacity, models and environmental impact. FAO Fish. Tech. Pap. (225):131 pp.

Dowidar, N.M. and M.A. Essa, 1988. Acclimation of red tilapia in Egypt. Proc. Conf. Develop. Fish. Resor., 6-8 Aug., Fac. Agric., Alexandria Univ., Egypt.

El-Dahhar, A.A., 1993. Maintenance and maxiumum growth requirenent for fry and finger-Lings of Nile Tilapia (Oreochromis niloticus) fed at varying feeding regimes. Alex. J. Agric. Res. 38(3):179- 
197.

El-Ebiary, E.H., 1994 . Studies on fish production . Relationship between nutrition and of Reproduction Tilapia sp. Ph.D. Thesis, Fac. Agric., Alex. Univ., Alex-anderia, Egypt.

E]-Ebiary, E.H. and M.A.A. Zaki, 1997 . The influence of stocking density, feeding Levels and frequency of feeding on growth rate and feed utilization of common carp (Cyprinus carpio). J. Agric: Res. Tarta Univ., 23(3) 229-239 pp.

Essa, M.A., 1993. Studies on the mass production of Nile tilapia, Oreochromis niloticus fry in concrete basins. Delta J. Sci., 17(1):183-195, Tanta Univ., Egypt.

Essa, M.A., 1999 . Low cost technologies for intensification of aquaculture systems and environmental impacts. A review, National Inst. Oceanography And Fish., Alex., 76pp.

Essa, M.A., 2000. The effects of feeding methods and regimes on performance of hybrid reared in cages. Egypt. J. Aquat. Biol. And Fișh., 4 (1): 67.84.

Essa, M.A., Z.M.El-Sherif, S.M.Abo El-Ezz and A.El-Moati,1989. Effects of water quality, food availability and crowding on rearing conditions and growth parameters of economical fish species grown under polyculture systems. Bull. Nat. Inst. Oceanogr. and Fish. ARE,15(1):125-134.

Essa, M.A. and M.E. Salama, 1989. Semi-intensive fish culture in an idle channel in Egypt J.Agric. Sci. Mansoura Univ., 14 (1): 169-178.

FAO, 1983. Freshwater aquaculture development in China. Report of the FAO/UNDP Study tour organized for Frensh speaking African countries May, 1980. FAO Fish. Tech. Pep, 215:125pp.

Golterman, H.L., R.S. Clymo and M.A.M.Ohnstad, 1978. Methods for physical and chemical analysis of fresh eaters. Inter, Biol. Progr. Hand books No.8, 213pp.

Hassanen, G.D.I., 1997. Effect of diet composition and protein level on growth, Body composition and cost of production of gilthead Sea bream (Sparus aurata). Egypt. J. Aquatic Biology and fisheries, 1(2): $1-18$.

Hepher, B., 1988. Nutrition of pond fishes. Cambridge Univ. Press, New york, NY 10022, USA, $387 \mathrm{pp}$.

Hepher, B. and Y. Pruginin, 1988. Commercial Fish farming with spechial references to fish culture in Israel. John Wiely and Sons, USA.

Holm,J.C.; T.Retstie and S.Bo, 1990. The effect of fish density and feeding regime on individual growth rate and mortality in rainbow trout (Onchorhynchus mykiss). Aquacu., 89:225-232.

Huet, M., 1972. Textbook of fish Culture- Breeding and Cultivation of fish Publ. By Editions . Ch. De Wyngaert, Brussels.

Kono, H. and Y. Nose, 1971. Relationship between the amount of food taken and growth of fishes. I. Frequency of feeding for a maximum daily ration. Bull. Jap.Soc.Sci. Fish.37: 169-194 pp.

Liao,C. and S.Chang, 1983. Studies on the feasibility of red tilapia culture in saline waters. Proc.Intern. Symp. On Tilapia in Aquac. Tel Aviv Univ. Israel pp. 524-533.

Loverich, G.F., 1996. Offshore aquaculture harvest and transport concept: feasibility and development . A report of Ocean Spar Technologies, LLC, Persuant to National Oceanic and Atmosph. Admin. A word No. NA56 FD 0071, Baibridge, Washington.

Maar, A.; D.F. Mairs and R.P. Malca, 1974. A total alkalinity atlas for Maine Lake water. Limnol. Oceanogt., 11:68-72.

Magouz, F.A., 2000. The Development of fish Resources in Egypt. P.35-43 In:Proc. Fish Resources Development, Fac. Agric., El-Mansoura Univ., May, 9, Egypt.

McGinty, A.S. and J.E.Rakocy, 1989.Cage culture of tilapia. Southern Regional Aquacutture Center (SRAC) Pub. No. 281, Texas.

Mckinley,T.R., 1994. Some effects of net pen rearing methods on feed conversion by age - O-Arctic Crayling in an interior Alaskan Lake. The Progressive fish Culturist, 26:19-24.

Meske, C., 1985. Fish aquaculture, technology and experiments- Pergaman Press Ltd., Headington Hill Hall, Oxford, Ox30BW, England, pp. 237.

Nour,A.M.; H. Mabrouk; E. Omar; M.A. Abo-El-Wafa ; A. Abo-Akkaada,1993. Effect of feeding levels and stocking densities on growth performance and feed utilization of Grey nullet (Mugil cephalus) 1. Intern. Symp. On Aquac. Techn, And Invest. Oppertu.,Riyadh (Saudi Arabia), 11-14 Apr.

Omar, E., 1984.Effect of type of feed, level and frequency of feeding on growth performance and feed utilaization by mirror carp (Cyprinus carpio L.)Ph. D. Agric. Thesis, Gottingen Univ. Gottingen, Germany.

Omar, E., 1986. Studies on Tilapia feeding. H1- Effect of different protein sources on growth performance And feed utilaization of fry. Egxpt. J. Anim. Prod. Vol. 26 No.2 pp. 171-83.

Smith, A.K. and S.J. Circle, 1978. Soybeans: Chemistry and Technology. 1. Proteins. Avi, Publishing, 
Westpoint, CT, 456pp.

Snedecor, G.W. and W.G. Cochran, 1974. Statistical Methods. $6^{\text {th }}$ ed. Iowa State Univ. Press, Ames Iowa, USA, $341 \mathrm{pp}$.

Swingle, H.S. 1969. Methods of analysis for water, organic matter and pond bottom soils in fisheries and research. Auburn Univ. ,Auburn, Alabama, 119pp.

Tacon,A.G.J, 1993. Feed ingredients for wormwater fish. Fish meal and other processed fee-dstuffs. FAO Fisheries Circular No. 856

Tacon,A.G.J, 1997. Feeding Tomorrow's Fish. Proc. Workshop of the CIHEAM Network on Technolosy of Aquaculture in the Mediterranean, Zaragoza, Spain. Vol.22:11-33.

Viola, S. ; S. Mokadi ; U. Rappaport and Y. Arieli, 1988. Partial And complete replacement of fish meal by soybean meal in feeds for intensive culture of hybrid tilapia (O.niloticus $\times$ O. aureus)

Watanabe,W.O. ; J.H. Clark ; J.B. Dunham; R.I, Wicklund and B.L. Olla, 1991. Culture of Florida red tilapia in marine cages : The effect of stocking density and dietary protein on growth. Aquaculture, 90(2): 123-134.

Zonneveld, N. and R. fadholi,1991. Feed intake and growth of red tilapia at different stocking densities in ponds in Indonesia. Aquaculture , $99: 83-94$. 